Ann. Rept. Kansai PI. Prot. (46): 1-6 (2004)

\title{
殺虫剂を混用したホルモン剂の花房散布による トマト果実の白ぶくれ症状抑制
}

\author{
井村岳男・西川 学 \\ Takeo Imura and Manabu Nishikawa: Control of white swelling spot of tomato \\ by the flower application of hormone added insecticide
}

\begin{abstract}
Summary
Population densities of the thrips, Frankliniella occidentalis Pergande (Fo) and F. intosa (Trybom) on tomato flowers were suppressed at low level by the flower application of 4-CPA (p-chlorophenoxyacetic acid) $15 \mathrm{ppm}$ added spinosad $50 \mathrm{ppm}$ at 3 to 4 days' intervals during flowering period. White swelling spot on fruits was reduced greatly by the flower application. The total amount of the flower application was about $1 / 100$ of the custom one. Spinosin residue on mature fruits by the flower application was fewer than by the custom one. The control effect for white swelling spot by the flower application of 8 insecticides were compared by releasing Fo adults. As a result, spinosad $50 \mathrm{ppm}$, tolfenpyrad $150 \mathrm{ppm}$ and fipronil 22 ppm were highly effective, while acephate 500 ppm, acrinathrin 30 ppm and chlorfenapyr 50 ppm were moderate, and malathion 250 ppm and acetamiprid 100 ppm were non-effective.
\end{abstract}

\section{緒訔}

トマト果実の白ぶくれ症状は，ヒラズハナアザミウマ Frankliniella intosa（Trybom）（以下ヒラズハナと略）と ミカンキイロアザミウマ Frankliniella occidentalis Pergande （以下ミカンキイロと略）の加害によって生ずる特異的 な症状であり，花に集まった雌成虫が子房に産卵し，幼 果期に産卵痕周辺が白く膨らむことで生ずることが明ら かになっている（村井，1988；片山，1998）。

ミカンキイロとヒラズハナは, 固場周辺の雑草などで 発生した成虫が次々に飛来して加害するが(新山と佐藤, 2000 ; 根来と柴尾，1998），トマトは開花期が長期にわ たるために，殺虫剂散布による防除では防除回数が多く なり, 生産者の経済的, 労力的負担が大きい。またミカ ンキイロは多種の殺虫剤に対して高度に抵抗性を発達さ せているため, 有効薬剤が少なく, 防除が困難になって いる（片山，1997）。

トマト栽培では着果や果実肥大の向上を目的として, 開花期の花に対する 4-CPA 剂（パラクロロフェノキシ 酢酸）などによるホルモン処理が広く行われている。谷 川ら（1994）は殺菌剤を加用したホルモン剤の花房散布 によって，薬剤使用量を著しく低減しながらトマト果実
の灰色かび病防除が可能であることを示した。このよう な病害虫の発生部位に限定した部分散布は, 農薬の散布 量, 残留量を軽減しながら病害虫を的確に防除できる合 理的な防除方法である（瀬崎ら，1988）。トマト果実の 白ふくく症状の原因となるアザミウマ類の加害部位は開 花期の子房に限定されるため, 開花期のホルモン処理時 に殺虫剂を混用する事によって白ぶくれ症状を予防する ことができれば, 散布に要する労力や薬剤の散布量を著 しく低減できる可能性がある。そこで, 殺虫剤を混用し たホルモン剤の花房散布によるトマト果実の白ぶくれ症 状抑制効果を検討した。

\section{材料と方法}

いずれの調査も奈良県橿原市四条町の奈良県農業技術 センター内のハウス栽培圃場で実施した。また調査にお いて放飼したミカンキイロは2001年から2003年に奈良県 内で採集し，マツの花粉を用いて継代飼育した系統を用 いた。

試験 1 ミカンキイロアザミウマに対するスピノサドと マラソンの花房散布の効果

調査戋場（面積 : $0.6 \mathrm{a}$, 品種:サターン）は2001年 4 
月20日に定植をおこなった。4 月27日，30日，5 月24日， 27 日の 4 回, ミカンキイロ成虫を約 100 頭ずつハウス全 体に放虫した。供試薬剤としてマラソン $50 \%$ 乳剤2000倍 とスピノサド $25 \%$ 水和剤 5000 倍を使用した。それぞれ慣 行の薬剤防除と同様に殺虫剂を株全体に散布する区（マ ラソン慣行散布区，スピノサド慣行散布区）と，4-CPA 0. 15\%液剂100倍液で希釈したものを，慣行のホルモン 処理と同様にハンドスプレーで花に散布する区（マラソ ン花房散布区，スピノサド花房散布区），ならびに殺虫 剂散布を行わない無処理区を設けた。処理株数はマラソ ン慣行散布区を 11 株, スピノサド慣行散布区を 7 株, マ ラソン花房散布区を 10 株, スピノサド花房散布区を 7 株, 無処理区を10株とし，反復は設定しなかった。また慣行 散布の両区と無処理区では，慣行のホルモン処理として 殺虫剂を混用しない 4-CPA 液剂100倍希釈液のみの散布 を花房散布区と同時に実施した。

ホルモン処理は 1 段花房の開花が始まった 4 月 25 日よ り開始し， 3 段花房の開花が終了するまで $3 \sim 4$ 日間隔 で継続した。ホルモン処理の散布量は殺虫剂混用の有無 に関わらず，花当たり $0.2 \mathrm{ml}$ 程度とした。マラソン花 房散布区は開花が始まった 4 月 27 日以降に12回，スピノ サド花房散布区は開花開始 6 日目の 5 月 7 日以降に10回 の殺虫剂混用処理をおこなった。慣行散布区の殺虫剤散 布はマラソン，スピノサドの両区ともに 5 月 7 日に 1 回 目 $(150 l / 10 \mathrm{a}) ， 5$ 月30日に 2 回目 $(400 l / 10 \mathrm{a})$ をおこ なった。虫数調査は, 花にミカンキイロの寄生を最初に 確認した 5 月 1 日から開始し，ホルモン処理の直前に開 花中のトマトの花房をたたいて, 白色板上に落下するミ カンキイロの成虫数を計数した。たたき落とした成虫は 回収せず，再放虫した。調査は 3 段花房の開花終了まで 継続した。

白ぶくれ果の発生率は，1～ 3 段果房で調査した。 1 段果房は 6 月 7 日， 2 段果房は 6 月 8 日〜 20 日，3 段果 房は 6 月 11 日 20日にかけて，すべての果実が調査可能 な程度に肥大した果房から随時見取り調査した。

試験 2 アザミウマ類に対するスピノサドの花房散布の 効果

調査圃場（面積 $0.6 \mathrm{a}$ ，品種:サターン）は2002年 4 月 24日に定植をおこない，定植時にイミダクロプリド粒剂 $1 \mathrm{~g} /$ 株を処理した。ミカンキイロ成虫を 4 月 30 日から 5 月31日にかけて, 約 4 日間隔で, 20から400頭ずつ, 計 1500頭をハウス全体に放虫した。供試薬剤としてスピノ サド $25 \%$ 水和剤 5000 倍を使用した。試験 1 と同様に，殺 虫剂を株全体に散布する慣行散布区と，4-CPA 液剤100 倍希釈液に混用して花房に散布する花房散布区，無処理
区を試験区として設定し，それぞれ試験区当たり 7 ない し 8 株× 3 反復で実施した。

ホルモン処理は 1 段花房の開花が始まった 4 月 30 日よ り開始し，5段花房の開花終了まで試験 1 と同様におこ なった。花房散布区はホルモン処理開始時より16回の殺 虫剂混用処理をおこなった。慣行散布区の殺虫剂散布は 5 月31日（333 $l / 10 \mathrm{a} ）$ におこなった。

虫数調査は 4 月 30 日より開始し, ホルモン処理の直前 に開花中のトマトの花房をたたいて，白色板上に落下寸 る全てのアザミウマ類個体数を計数した。落下したアザ ミウマは可能な限り全て $70 \%$ エタール水溶液に浸漬し て持ち帰り，実体顕微鏡下で観察して，幼虫と成虫別に 計数した。また, 成虫は千脇ら（1994）の検索表に基づ いて同定し，ミカンキイロ，ヒラズハナ，ネギアザミウ マThrips tabaci Lindeman, およびその他のアザミウマ に分けた。持ち帰りサンプル中の成幼虫および種ごとの 構成比率を先のたたき落とし個体数に乗じて, 種ごとの 寄生個体数とし, 花房当たり個体数を推定した。調査は 1 段花房から 5 段花房の開花終了まで継続した。

白ぶくれ果の発生率は，1 段果房が 5 月27日から 6 月 7 日， 2 段果房が 6 月 7 日から 6 月 25 日， 3 段果房が 6 月 10 日から 7 月 1 日， 4 段果房が 6 月 21 日から 7 月 9 日, 5 段果房が 6 月 21 日から 7 月 9 日にかけて, すべての果 実が調査可能な程度に肥大した果房から随時見取り調査 した。

試験 38 種殺虫剤のミカンキイロアザミウマに対する 効果

調査圃場（面積 $0.5 \mathrm{a}$, 品種 : ホーム桃太郎）は2003 年 5 月 6 日に定植をおこない, 定植時にピメトロジン粒 剂 $1 \mathrm{~g}$ /株を処理した。 6 月 3 日（ $3 \sim 4$ 段花房開花期） に第 1 表に示した 8 薬剤を 4-CPA 液剤100倍液で希釈し たものを，開花中の花にハンドスプレーで散布した。ま た対照区として殺虫剤を混用しない区を設けた。各区 5 株について， 1 株当たり開花中の $2 \sim 4$ 花（区当たり 14 ～17花）に処理をおこない, 処理花房の未開花もしくは 開花終了した花蕾は除去した。風乾後処理花房に果実袋 を被せて, ミカンキイロ +成虫を花房当たり 3 頭投入し, 2 日後の 6 月 5 日に除袋した。 6 月 11 日に処理果房の白 ぶくれ症状発生果実数を調査した。

試験 4 スピノサド花房散布における投下薬量と残留濃 度

試験 2 において，1～ 3 段花房に対する投下薬量と農 薬残留濃度を調査した。1 3 段花房のホルモン処理時 に処理花数を計数して, 花房散布区の散布薬量を算出し た。また 1 段果房は 6 月 18 日， 2 段果房は 7 月 9 日， 3 
段果房は 7 月 22 日に収穫適期になった果実を収穫し，果 実のへタを除去して農薬残留濃度を分析した。分析方法 は環境省告示試験法（環境省告示1999）に基づいておこ ない, 農薬成分スピノシン $\mathrm{A}$ とスピノシン $\mathrm{D}$ を 2 反復 で測定した（アセトニトリル抽出, 酢酸エチル転溶, シ クロヘキシルカラム精製, シリカゲルカラム精製, HPLC（UV250 nm）定量）。

\section{結果および考察}

試験 1 ミカンキイロアザミウマに対するスピノサドと マラソンの花房散布の効果

各試験区の花房におけるミカンキイロ成虫数の推移を 第 1 図に，白ぶくれ果率を第 2 図に示した。マラソン処 理では，慣行散布区，花房散布区ともにミカンキイロの 発生量が無処理区と同程度かむしろ高く, 白ぶくれ果率 も同様であり，殺虫剤処理による抑制効果はなかった。 スピノサド慣行散布区では 1 回目の散布直後にミカンキ イロの急激な密度減少が観察され，散布による明らかな 防除効果が見られたが，2回目の散布時には散布直前に 個体数が急減したため, 防除効果は確認できなかった。

\section{a. スピノサド処理}
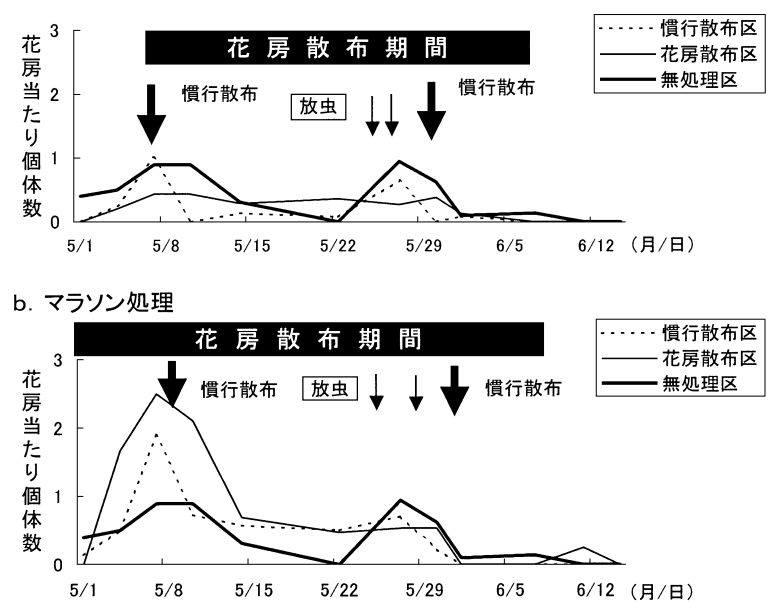

第 1 図 殺虫剂の処理方法がトマト花房のミカンキイロアザミ ウマの発生量におよぼす影響

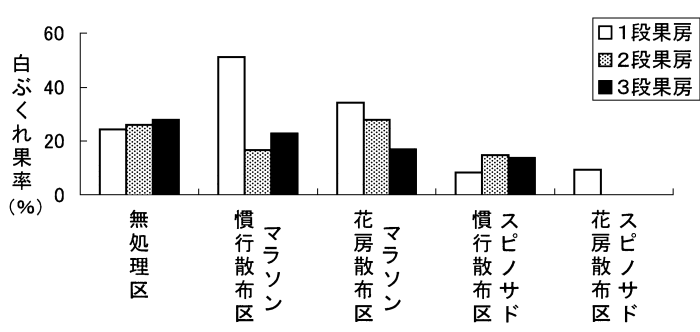

第 2 図 殺虫剂の処理方法がトマト果実の白ぶくれ果率におよ ぼす影響
白ぶくれ果率は 1 〜 段果房のいずれも無処理区よりも やや低くなる傾向が見られ，ある程度の白ぶくれ症状抑 制効果があると考えられた。これに対しスピノサド花房 散布区では, ミカンキイロの発生量は調査期間中に大き な変動がなく，おおむね無処理区よりは低密度であった ものの, 明確な防除効果は認められなかったが, 白ぶく れ症状は 1 段果房以外では全く発生せず，高い抑制効果 が見られた。このことから，スピノサドを混用したホル モン処理を継続的に実施することにより，極めて高い白 ぶくれ症状抑制効果が期待できると考えられた。

試験 2 アザミウマ類に対するスピノサドの花房散布の 効果

第 3 図に各試験区の花房におけるアザミウマ類個体数 の推移を示した。いずれの試験区でもミカンキイロとヒ ラズハナが優占する傾向にあり，ネギアザミウマの発生 も若干みられた。無処理区では 6 月以降アザミウマの密 度が急増したが, 慣行散布区と花房散布区では増加が見 られず，調査期間中は低密度で推移し，スピノサドの両 処理によって花房に寄生するアザミウマ類全体の発生量 を低密度に抑える効果があると考えられた。

第 4 困に各試験区の白ぶくれ果率を示した。混用区で
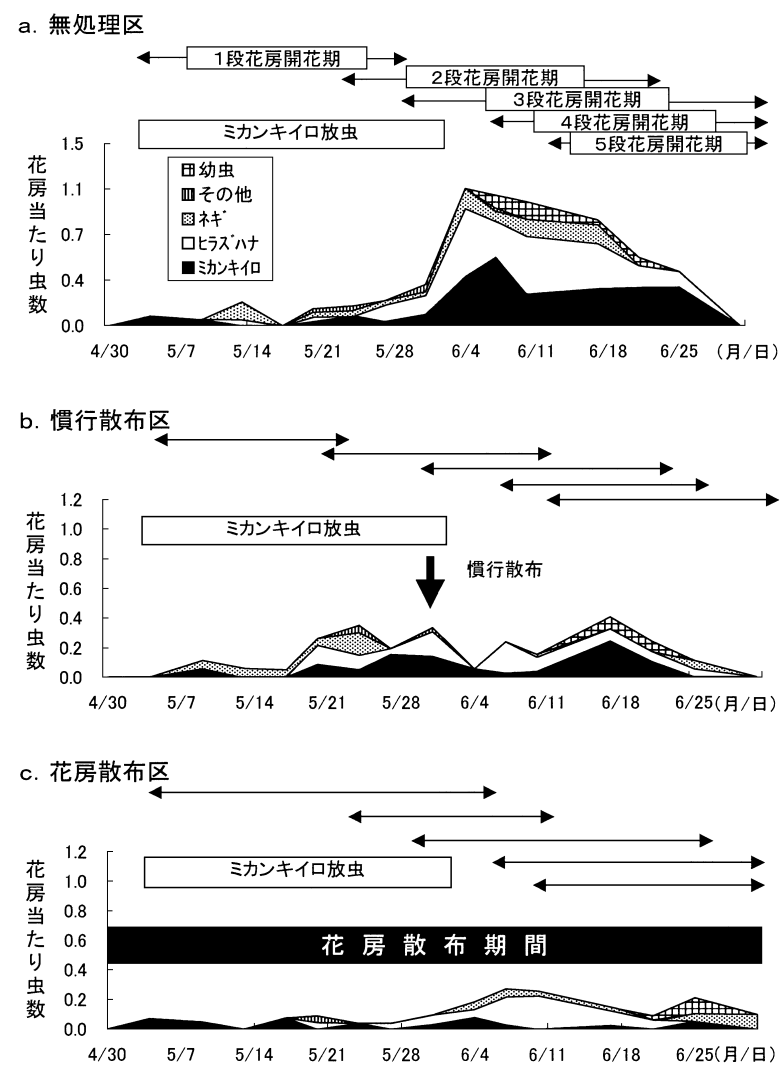

第 3 図 スピノサドの処理方法がトマト花房のアザミウマ類の 発生量におよぼす影響 


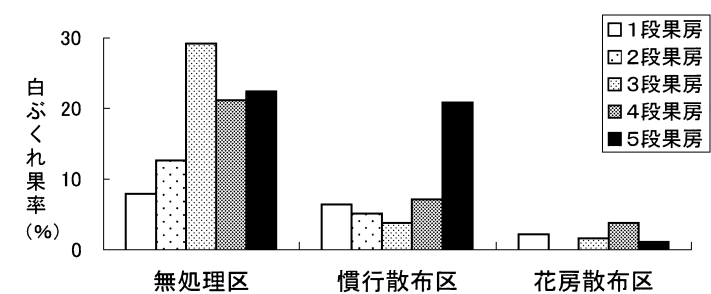

第4図 スピノサドの処理方法がトマト果実の白ぶくれ果率に およばす影響

は 1 から 5 段果房のいずれにおいても無処理区と比較し て白ぶくれ症状の発生が著しく少なく，高い抑制効果が 見られた。慣行散布区では $2 \sim 4$ 段果房では無処理区よ りも白ぶくれ症状の発生が少なかったが，1 段果房と 5 段果房では同程度の発生が見られた。慣行散布区の散布 日は $2 ， 3$ 段花房の開花期に当たることから，1 段果房 で白ぶくれ症状が多かったのは，開花期に殺虫剤処理を 受けていなかったためと考えられる。また 4 段果房まで はおそらく散布した薬剤の残効によって白ぶくれ症状を 抑制し，5段果房では残効が切れたために再び白ぶくれ 症状が増加したと考えられる。

以上の結果から，スピノサド処理は，試験 1 と同様に 花房に寄生するミカンキイロだけでなく，ヒラズハナを 含めたアザミウマ類全体の発生を低密度に抑える効果が あり，さらにホルモン剂への混用処理を継続した場合に は白ふくれ症状を長期間に渡って著しく抑制できると考 えられた。

試験 38 種殺虫剤のミカンキイロアザミウマに対する 効果

第 1 表に各試験区の白ぶくれ果率を示した。トルフェ ンピラド，フィプロニル，スピノサドを処理した区では 白ぶくれ症状は全く発生せず, 高い抑制効果が見られた。 アセフェート, アクリナトリン，クロルフェナピルを処 理した区でもある程度白ぶくれ果の抑制が見られた。こ
第 1 表 各種殺蛳の花房散布がトマト果実の白ぶくれ果率に およぼす影響

\begin{tabular}{|c|c|c|c|}
\hline 供試薬剤 & 希釈倍率 & 処理花数 & $\begin{array}{c}\text { 白ぶくれ } \\
\text { 果率 }(\%)\end{array}$ \\
\hline アセフェート $50 \%$ 水和剤 & 1000 & 16 & 6.3 \\
\hline マラソン50\%乳剤 & 2000 & 16 & 31.3 \\
\hline アクリナトリン $3 \%$ 水和剤 & 1000 & 17 & 11.8 \\
\hline アセタミプリド $20 \%$ 水溶剤 & 2000 & 15 & 33.3 \\
\hline トルフェンピラド15\%乳剤 & 1000 & 17 & 0 \\
\hline クロルフェナピル $10 \%$ 水和剤 & 2000 & 15 & 13.3 \\
\hline フィプロニル $4.4 \%$ 水和剤 & 2000 & 15 & 0 \\
\hline スピノサド $25 \%$ 水和剂 & 5000 & 17 & 0 \\
\hline 無処理 & & 14 & 35.7 \\
\hline
\end{tabular}

*いずれの処理区も 4-CPA 0.15\%液剂100倍液で希釈して処理 した

**無処理区は 4-CPA のみの処理をおこなった

れに対し，マラソン，アセタミプリドを処理した区の白 ぶくれ果率は無処理とほとんど差がなかった。このよう な白ぶくれ症状抑制効果の薬剤間に見られる差違は，お そらくミカンキイロに対する殺虫剂感受性程度や残効性 を反映しているのだろう。現在フィプロニル以外の剤は 全てトマトに対して農薬登録があり，このうちトルフェ ンピラドは試験 $1 ， 2$ のスピノサドと同様に，ホルモン 処理時に混用して継続的な処理をおこなうことで，高い 白ぶくれ症状抑制効果が期待できると考えられる。

試験 4 スピノサド花房散布における投下薬量と残留濃 度

慣行散布区の $10 \mathrm{a}$ 当たり散布量は $333 l$ （株当たり $220 \mathrm{ml}$ ）であったのに対し，花房散布区の 1 ～ 3 段目ま での処理花数は292花であり, 散布総量は $10 \mathrm{a}$ 当たり $3.9 l$ (株当たり $2.7 \mathrm{ml}$ ) と算出され, 慣行散布区と比 較して投下薬量は $1 / 100$ 程度と著しく低かった。

残留分析の結果を第 2 表に示した。残留濃度は慣行散

第2 表 スピノサドの処理方法がトマト果実のスピノシン残留濃度におよぼす影響

\begin{tabular}{|c|c|c|c|c|}
\hline & \multirow{2}{*}{ 成分 } & \multicolumn{3}{|c|}{ 残留濃度（ppm） } \\
\hline & & 花房散布区 & 慣行散布区 & 無処理区 \\
\hline \multirow[t]{3}{*}{1 段果房 } & スピノシン A & $<0.02$ & 0.04 & $<0.02$ \\
\hline & スピノシン D & $<0.02$ & $<0.02$ & $<0.02$ \\
\hline & スピノシン総量 & $<0.02$ & 0.04 & $<0.02$ \\
\hline \multirow[t]{3}{*}{2 段果房 } & スピノシン A & $<0.02$ & $<0.02$ & $<0.02$ \\
\hline & スピノシン D & $<0.02$ & $<0.02$ & $<0.02$ \\
\hline & スピノシン総量 & $<0.02$ & $<0.02$ & $<0.02$ \\
\hline \multirow[t]{3}{*}{3 段果房 } & スピノシン A & $<0.02$ & $<0.02$ & $<0.02$ \\
\hline & スピノシン D & $<0.02$ & $<0.02$ & $<0.02$ \\
\hline & スピノシン総量 & $<0.02$ & $<0.02$ & $<0.02$ \\
\hline
\end{tabular}

*検出限界 $0.02 \mathrm{ppm}$ 
布区，花房散布区のいずれも低く，慣行散布区の 1 段果 房（薬剤散布18日後）に低い濃度のスピノシン A が検 出された以外はすべて検出限界以下だった。

谷川ら（1994）はトマト果実の可食部におけるプロシ ミドンの残留濃度を, 収穫 3 日前の圃場全面散布と開花 時の圃場全面散布, 花房散布の場合で比較しており, 収 穫 3 日前散布では $0.8 \mathrm{ppm}$ の残留を検出したのに対し, 開花時の散布では花房散布と國場全面散布のいずれも検 出限界以下（<0.1 ppm）であった。今回の調査でもス ピノサドの残留が検出されたのは，肥大期の果実に殺虫 剂を散布した慣行散布区の 1 段果房のみであり，開花期 の散布では株全体散布（慣行散布区の $2 ， 3$ 段果房）と 花房散布（花房散布区）のいずれも検出限界以下だった。 実際の生産現場におけるアザミウマ防除を想定すると， 開花期間中に慣行の圃場全面散布を繰り返しおこなった 場合には，すでに防除の必要がない低段位の果実に常に 薬剤がかかるため, 今回の結果よりもさらに残留濃度は 高くなる可能性があるが，花房散布の場合には常に開花 中の花房のみに薬剤を散布するので，残留濃度は常に低 いと考えられる。今回は上段花房に花房散布をおこなっ た場合の下段へのドリフトは調査していない。しかし， 花房散布を 3 ～ 4 日間隔で 5 段花房まで継続するという 試験条件下において，1３段果房の収穫果実の残留が 検出限界以下であったことから，収穫果実へのドリフト の影響は軽微であったと考えられる。また先の谷川ら （1996）は，6段花房にプロシミドンを花房散布した直 後に採集した 1 から 5 段の花または果実の残留を調査し たところ，いずれも検出限界以下（<0.1 ppm）だった と報告している。これらのことから，花房散布による下 段位へのドリフトの影響はごく僅かであると推測される が，今後さらにサンプル数を増やして詳細に調査する必 要がある。

\section{総合考察}

試験 1 および 2 の結果から，スピノサドを混用した花 房へのホルモン処理は, 発生するアザミウマの種類によ らず, 白ぶくれ症状抑制効果が著しく高いと考えられた。 アザミウマ類による白ふくく症状は，加害時期が開花期 であるため，常発地ではかなり長期間にわたって，繰り 返し防除を行わ放ばならず，経済的，労力的負担が大き い。しかし, 今回の試験で示したように, 開花時のホル モン処理という慣行の管理に殺虫剤を組み込むことで防 除可能であれば，アザミウマに対する殺虫剂散布をかな り省略することが可能である上に，投下薬量も著しく少 なくなることから，殺虫剤散布にかかる経費や労働量を
軽減すると考えられる。また，果実への残留濃度も低く， 極めて安全性が高い処理方法と言える。

現在の農薬登録制度においては，このような部分散布 法は圃場全面散布と同様に使用回数をカウントする必要 があり，スピノサドのトマトにおける登録条件は， 1 作 当たりの散布回数が 2 回となっている。慣行のホルモン 処理にスピノサドを継続して混用した場合, 今回の試験 では散布回数は 1 から 5 段花房で計16回と莫大な回数に なった。そのため, 実際の株当たりの投下薬量は全面散 布と比較して著しく少ないにも関わらず，農薬使用基準 の上からは使用が出来ないという矛盾が生じている。し かしながら, 今回行った花房散布による防除は, 経費や 労力を軽減しながら環境負荷を低減し, 安全性を高める ことができるきわめて合理的な技術である。

試験 3 では, 継続的な処理は行っていないが，スピノ サド以外にもトルフェンピラドとフィプロニルの効果が 高く, アセフェート, アクリナトリン, クロルフェナピ ルもある程度の効果が見られた。これらのうちフィプロ ニルはトマトに作物登録がないが, トルフェンピラドと クロルフェナピルは 1 作当たり 2 回, アセフェートとア クリナトリンは 3 回の散布が可能であり, これらの剂を, アザミウマの発生種や発生量に応じてローテーションす ることによって，栽培上は防除することができると考え られる。しかし, 異なる薬剤の混用は法的な問題はない ものの, 混用による毒性の相乗効果が未知であるため, 農業者の自己責任に委㸚られているのが現状であり，指 導機関が混用を指導するのが事実上不可能な状態にあ る。しかし，このような技術はトマトだけでなくナスや ブドウなど, 開花期にホルモン処理を行うほかの作物に 対しても応用可能と考えられ，農業者のニーズは高いも のと思われる。今後はホルモン剂と殺虫剤の混合剤の新 規開発を期待したい。

\section{摘 要}

スピノサド水和剂5000倍を混用した 4-CPA 剂（パラ クロロフェノキシ酢酸）100倍液の花房散布を開花期間 中 3 ないし 4 日間隔で実施することで, トマトの花に寄 生するミカンキイロアザミウマとヒラズハナアザミウマ の発生を低密度に抑えられ, 白ふくく症状は著しく減少 した。花房散布の投下薬量は株全体散布の約 $1 / 100$ にな り，果実への残留濃度も花房散布の方が少なかった。 8 種の殺虫剂について 4-CPAに混用して花房散布をおこ なった後にミカンキイロアザミウマ成虫を接種して白ぶ くれ果率を比較したところ，スピノサド水和剂5000倍と トルフェンピラド乳剤1000倍, フィプロニル水和剤2000 
倍は抑制効果が高く, アセフェート水和剂1000倍とアク リナトリン水和剤1000倍，クロルフェナピル水和剤2000 倍も中程度の効果が見られたが，マラソン乳剂2000倍, アセタミプリド水溶剂2000倍は効果がなかった。

\section{引用文献}

1）千脇健司・佐野敏広・近藤 章・田中福三郎（1994）植物 防疫 $48: 521-523$.

2）片山晴喜（1997）植物防疫 $51: 43-46$.
3）片山晴喜（1998）植物防疫 52: 176-179.

4）環境省告示 (1999) スピノサド試験法 (平成11年 4 月19日).

5）村井 保（1998）島根農試研報 23:1-73.

6）根来 実・柴尾 学（1998）関西病虫研報 40:135-136.

7) 新山徳光・佐藤正彦（2000）秋田農試研報 $41: 17-29$.

8）瀬崎滋雄・谷川元一・井上雅央（1988）近畿中国農研 75 : 50-54.

9）谷川元一・木村 桐 - 中野智彦・萩原敏弘 - 岡山健夫 （1994）奈良農試研報 $25: 21-24$. 